\title{
IMPLICATIONS OF PETROGRAPHY AND GEOCHEMISTRY OF ATHINIOS METAMORPHIC UNITS USING PXRF AND GIS ANALYSES IN THERA (SANTORINI, GREECE).
}

\author{
Pasqualon N.G. ${ }^{1}$, Santos K.N.S. ${ }^{2}$, Marsellos A.E. ${ }^{3}$ and Kyriakopoulos K. ${ }^{4}$ \\ ${ }^{1}$ Universidade Federal do Rio Grande do Sul (UFRGS), Av. Bento Gonçalves, 9500 - Agronomia, \\ Porto Alegre-RS, Brazil,90650-001,nati_pasqualon@yahoo.com.br \\ ${ }^{2}$ Universidade Federal do Rio de Janeiro (UFRJ), Av. Athos da Silveira, 274, Campus Ilha do \\ Fundão, Rio de Janeiro-RJ, Brazil, 21949-900,kathelynunes@gmail.com \\ ${ }^{3}$ Hofstra University, Hempstead, New York, U.S.A., 11549-1000, antonios.marsellos@hofstra.edu \\ ${ }^{4}$ National \& Kapodistrian University of Athens, Zografou, Athens, Greece, 157 84, \\ ckiriako@geol.uoa.gr
}

\begin{abstract}
Santorini metamorphic basement is part of the metamorphic complex known as Cycladic Massif, which was formed during the subduction of the Mediterranean lithosphere underneath the Aegean microplate. The two main components of the exposed basement are a complex of low-grade schists and phyllites, which are well exposed in Athinios harbour and overlaid by the crystalline limestones exposed in Mount Profitis Ilias and Mount Mesa Vouno. The Eocene and Miocene metamorphic units present evidence of dynamic metamorphism, and possibly are influenced by a granitic intrusion in Miocene. In this study, a new methodology was developed to study the two units exposed at Athinios. Structural data and rock samples were analysed using a Portable X-Ray fluorescence (PXRF) spectrometer analysis at Athinios and integrated in aGIS (Geographical Information System) software to understand the spatial geochemical variations in the area. PXRF results for the two metamorphic units showed similar geochemical patterns. However, a contour map of $\mathrm{TiO}_{2}(\%)$ for the metamorphic rocks of the Athinios area presented intermittent zones of high and low $\mathrm{TiO}_{2}$ concentrations which could indicate hydrothermal remobilization of light elements and an enrichment in Ti. Petrography and geochemistry results suggest the local existence of a ductile-brittle shear zone between the two metamorphic units.

Keywords: Petrography, geochemistry, Athinios, Eocene and Miocene metamorphic units, Santorini ductile-brittle shear zone.
\end{abstract}

\section{Introduction}

The Hellenic Volcanic Arc tectonics has been influenced by the interaction between the northward subducting African plate and the overriding Aegean micro-plate. Santorini Island belongs to the Hellenic volcanic arc located at the South Aegean Sea. Santorini metamorphic basement is part of the metamorphic complex called Cycladic Massif. In the study area, a metamorphic unit with Miocene cooling ages is juxtaposed structurally below an Eocene metamorphic unit (Marsellos et al., 2013). Both units have undergone two stages of the Alpine metamorphism: at Eocene 


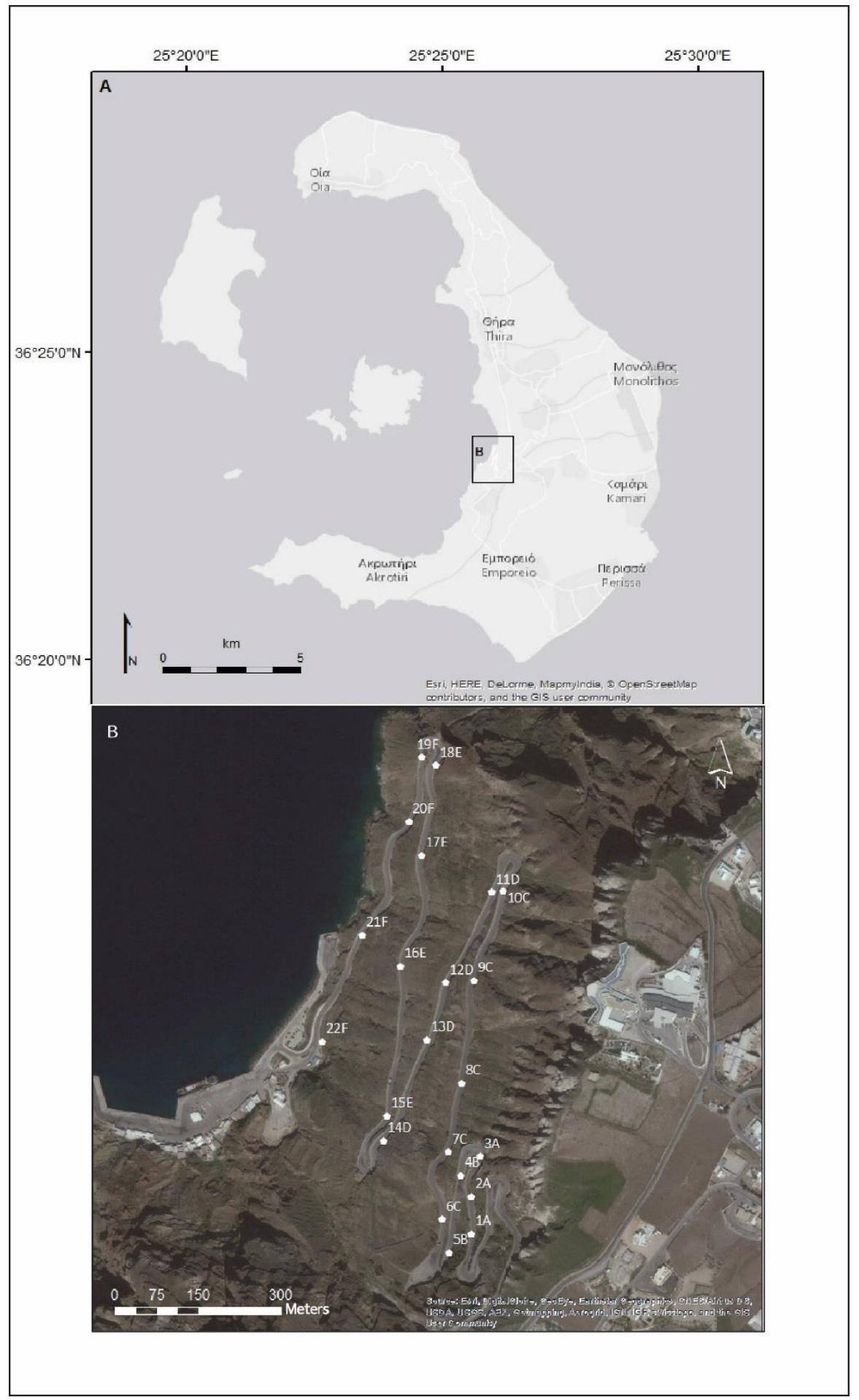

Figure 1 - A) Athinios harbour location within Santorini. B) Map of samples collected for petrography in Athinios. Each letter corresponds to a road-segment following a descending direction where the sample was collected. 
high-pressure event producing blueschist-facies assemblages and a Miocene medium-pressure event producing greenschist-facies assemblages (Altherr et al., 1982 Andriessen et al., 1979). The two metamorphic units are composed of low-grade metapelites and were exhumed during multiple events and via multiple detachment faults as previously described in other areas in the Aegean as well (e.g. Lister et al., 1984; Fassoulas et al., 1994; Thomson et al., 1999; Ring et al., 2010; Keay et al., 2001; Jolivet et al., 2003; Marsellos et al., 2010). The Santorini metamorphic rocks have shown an interesting petrography and geochemistry (e.g. Davis and Bastas, 1978 and Skarpelis and Liati, 1990). This work presents a petrographic and geochemical study of the two metamorphic units exposed along the road of Athinios harbour (Fig.1) through the use of optical microscopy, PXRF (Portable X-ray Fluorescence) and GIS (Geographical Information System) analyses. A discussion follows about the interesting petrographic, geochemical, and structural patterns of the two metamorphic units.

\section{Santorini tectonic and geological setting}

The Hellenic Volcanic Arc tectonics (Fig.2) has been influenced by the interaction of the northward African subducting slab and the overriding Aegean plate. The African plate experiences episodic rollback (Ring et al., 2010; Marsellos et al., 2012), and the overriding Aegean plate follows a back arc extension. The Aegean Sea is an excellent example of episodic extension and exposes a wide range of regional detachment faults (e.g. Fassoulas et al., 1994; Thomson et al., 1999; Jolivet et al., 2003; Marsellos and Kidd, 2008; Ring et al., 2010; Skourtsos and Lekkas, 2011) and localized multidetachments with episodic extension direction as observed in Kythera and Peloponnese. The Hellenic arc has recorded a local arc-parallel extension along a

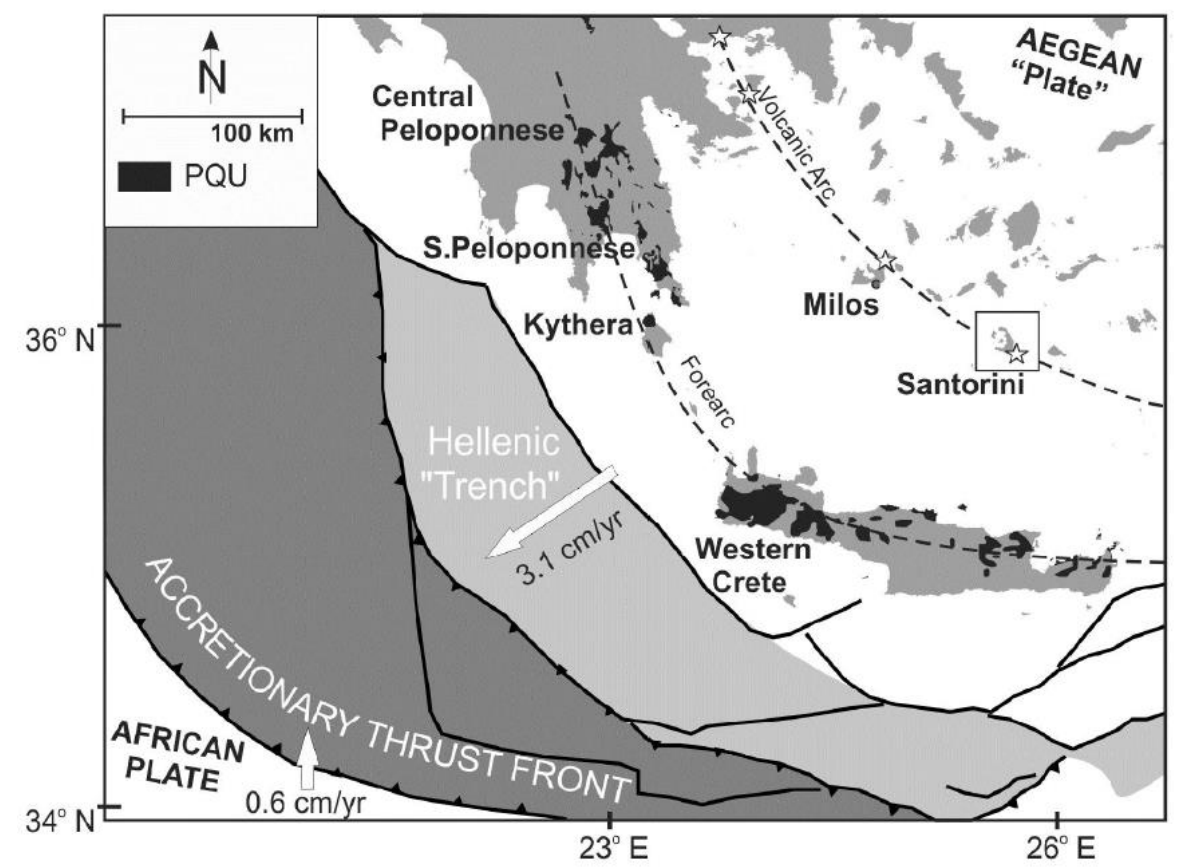

Figure 2 - Tectonic setting of the Hellenic volcanic arc and forearc which are the result of the interaction between the northward African subducting plate and the overriding Aegean microplate. Present GPS Eurasia-Africa relative velocity and average western Hellenic ArcAfrica relative velocity (derived from the average of five stations in western-central Crete, Kythera, and south Peloponnese) after McClusky et al. (2000). 
NW-SE direction from southeastern Peloponnese through Kythera and western Crete (Marsellos and Kidd, 2008). In the Hellenic Trench the tensional field causes low dip angle thrust faults trending NW-SE and dipping NE (Fytikas and Vougioukalakis, 2005), while in the volcanic arc the crust is dominated by a tensional field with a NW-SE direction, resulting in normal faults which strike NESW. (e.g. Jolivet et al., 2003; Papazachos et al., 2005). In Santorini, the exposed schists and phyllites at Athinios have shown Miocene $(10.9 \pm 0.7 \mathrm{Ma}, \mathrm{ZFT} ; 9.4 \pm 0.3 \mathrm{Ma}, \mathrm{AHe})$ and Eocene $(46.3 \pm 2.8$ Ma, ZFT; $49.34 \pm 2.9 \mathrm{Ma}$, AHe) exhumation ages (Marsellos et al., 2013) implying a thermal reset in Miocene which is possibly related to a granitic intrusion that took place at $9.5 \mathrm{Ma}$ (Skarpelis et al., 1992).

\section{Methodology}

\subsection{Sample locations}

The occurrence of metamorphic rocks in Santorini Island is restricted to the localities of Perissa in the southeast, to the outer rim of the island and to the caldera walls at Athinios harbour. The area chosen for this work within Santorini Island is Athinios harbour, which is located in the eastern portion of the island (Fig.1A) and shows very well preserved metamorphic rocks and structures for a length of at least $3 \mathrm{~km}$ and a height of $215 \mathrm{~m}$. For the PXRF analysis, 132 sites were selected within 20-30 m intervals along the $3 \mathrm{~km}$ descending road towards Athinios harbour (Fig. 3) and 22 sites for microscopic analysis of rock thin sections.

\subsection{Geochemistry and Petrography}

For the petrographic work a Nikon Eclipse E400 microscope was used, with an attached Nikon E995, 34.4 megapixel Digital camera for the photomicrographs. Analysis was completed with 22 thin sections from Athinios metamorphic rock units. PXRF analysis performed in 132 samples during three days using the battery-powered portable X-ray fluorescence spectrometer X-MET 5100 - Oxford Instruments. The modes of operation were standard element ('soil') and the light element analysis programme (LEAP) which provided analyses for $\mathrm{Al}, \mathrm{Si}, \mathrm{P}, \mathrm{S}, \mathrm{Cl}, \mathrm{K}, \mathrm{Ca}, \mathrm{Na}, \mathrm{Mg}, \mathrm{Ti}, \mathrm{Cr}$, $\mathrm{Mn}, \mathrm{Fe}, \mathrm{Cu}, \mathrm{Zn}, \mathrm{As}, \mathrm{Rb}, \mathrm{Sr}, \mathrm{Pb}$. Each of the 132 samples was analysed 3 times using count times of 60 seconds per measurement. The ppm values obtained were inserted in an Excel file, the average value for the 3 measurements was taken and the final values were converted to oxide percentages. Finally, a series of graphs and contour maps were generated through a GIS software for the spatial analysis of major, minor and trace elements.

\subsection{Geographical Information System (GIS)}

PXRF measurements with sample coordinates, altitude, lineations and element analysis was imported in a GIS software (ArcGIS 10.2 by ESRI) to study the spatial distribution of major and minor elements in the area. Using a previous methodology of k-means cluster analysis in a GIS software (Marsellos et al., 2013) the two metamorphic units were separated through their stretching lineations (with clusters at NNW-Miocene and at NNE-Eocene) values. A representative average of the major elements geochemistry of each unit was calculated, which is summarized in Table 1.

\section{Results}

\subsection{Petrology}

The Miocene unit rocks show a gray to pale green colour, a prominent foliation with a stretching lineation trending NNW, and mineral composition of chlorite, muscovite, quartz, albite and minor calcite. Some outcrops presented alternation between schists and layers from 0,5 up to $2 \mathrm{~m}$ thick of marbles, which have light gray colour and granoblastic texture, composed mostly of fine calcite grains. The Eocene unit has an orange-reddish colour due to alteration and where best preserved, a pale green colour, with a silky luster at its surface composed of very fine grains barely identified by 
the naked eye. On the foliation surface a stretching lineation trending NNE was identified. Both metamorphic units present sets of faults filled in by quartz and calcite and dynamic metamorphism features such as quartz and albite porphyroclasts and aggregates. It was possible to find within the two units chlorite-quartz-mica schists, mica-calcite-quartz schists to quartzites, phyllites, calcphyllites and calcite marbles (Fig.4).

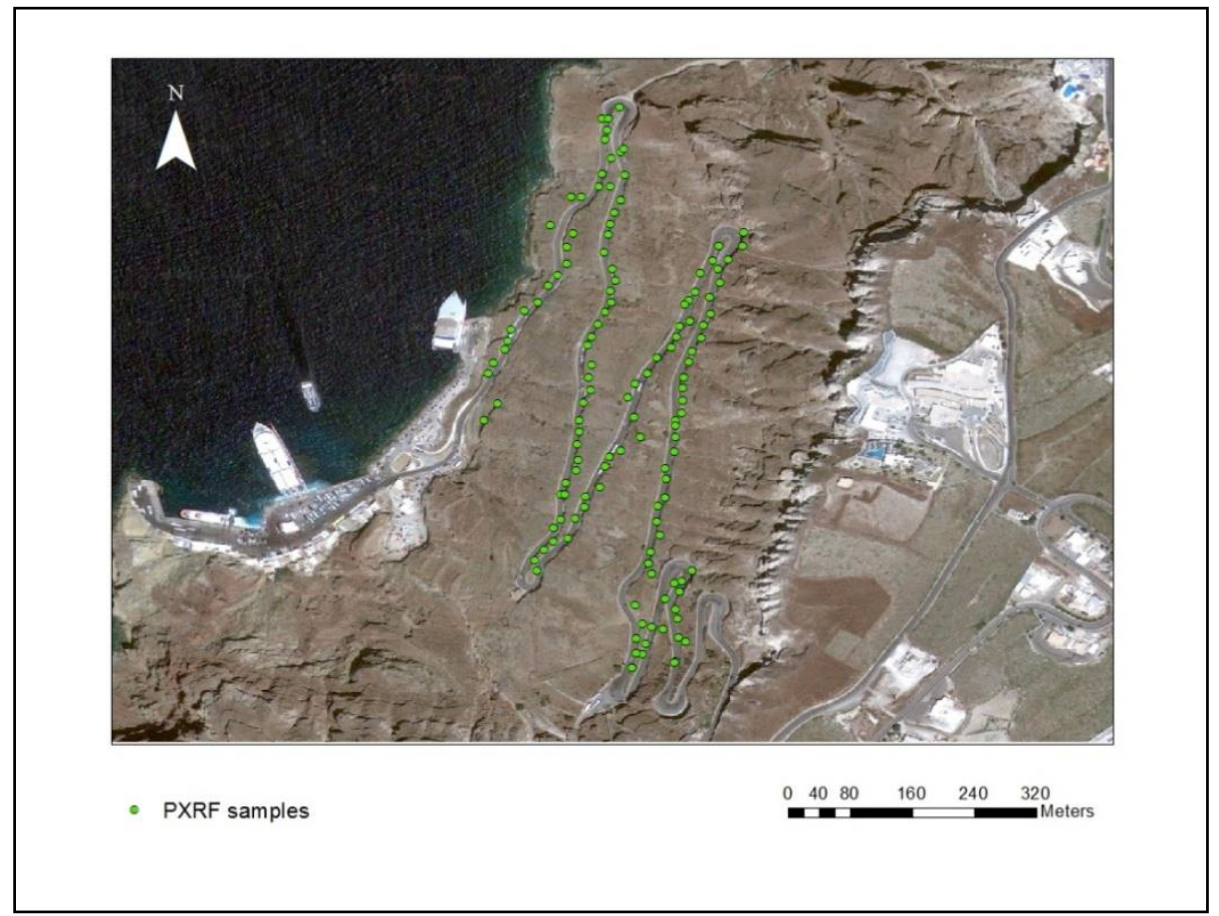

Figure 3 - Location of 132 samples collected in Athinios for PXRF analysis.

In general, schists and phyllites from both metamorphic units host a well-developed foliation, with a visible crenulation cleavage and a main mineralogical composition of quartz, muscovite, albite, chlorite, biotite, calcite, and rutile and iron oxides as accessory phases. Rocks present a granolepidoblastic texture; micas and chlorite aligned in a preferential direction define the lepidoblastic texture and phyllites' optical fissility, while quartz, calcite and feldspar define the granoblastic texture.

Marble lenses are located within the schists and phyllites of Athinios. They are composed of fine to medium grain granoblastic calcite and they may also contain a few percentage of quartz and white mica.

Quartz occurs as porphyroclasts and as recrystallized polycrystalline quartz in the matrix of the phyllites or schists. Quartz porphyroclasts have an undulose extinction (Fig.4h), with a sub-angular shape. Quartz porphyroclasts have been fractured or rotated showing bookshelf structures. Some grains also present deformation bands and gradual evolution to sub grains in the external portion (Fig.4f). The recrystallized quartz grains in the matrix show a homogeneous grain size and vary from almost undeformed to very well oriented and present irregular grain boundaries. Albite has been identified in the matrix with quartz, and some of them are substituted by calcite and sericite and albite porphyrclasts presented polysynthetic twinning, sub to well-rounded shape, and it is possible to observe that they suffered rotation within the matrix (Fig.4e). Micas are aligned in a preferred orientation defining the lepidoblastic texture of the rocks (Fig.4b and 4c). C-S structures marked by muscovite surrounding feldspar porphyroclasts were observed. Chlorite occurs with a lamellar habit and dark green to brownish pleochroism under plane polarized light. Most of chlorite 
was found within mica domains in the matrix. Calcite appears substituting plagioclase in the matrix or cementing the grains with an anhedral shape and lamellar twinning, with high order birefringence colors. In the marble lenses calcite presented a rhombohedral cleavage and lamellar mechanic twinning (Fig.4d).

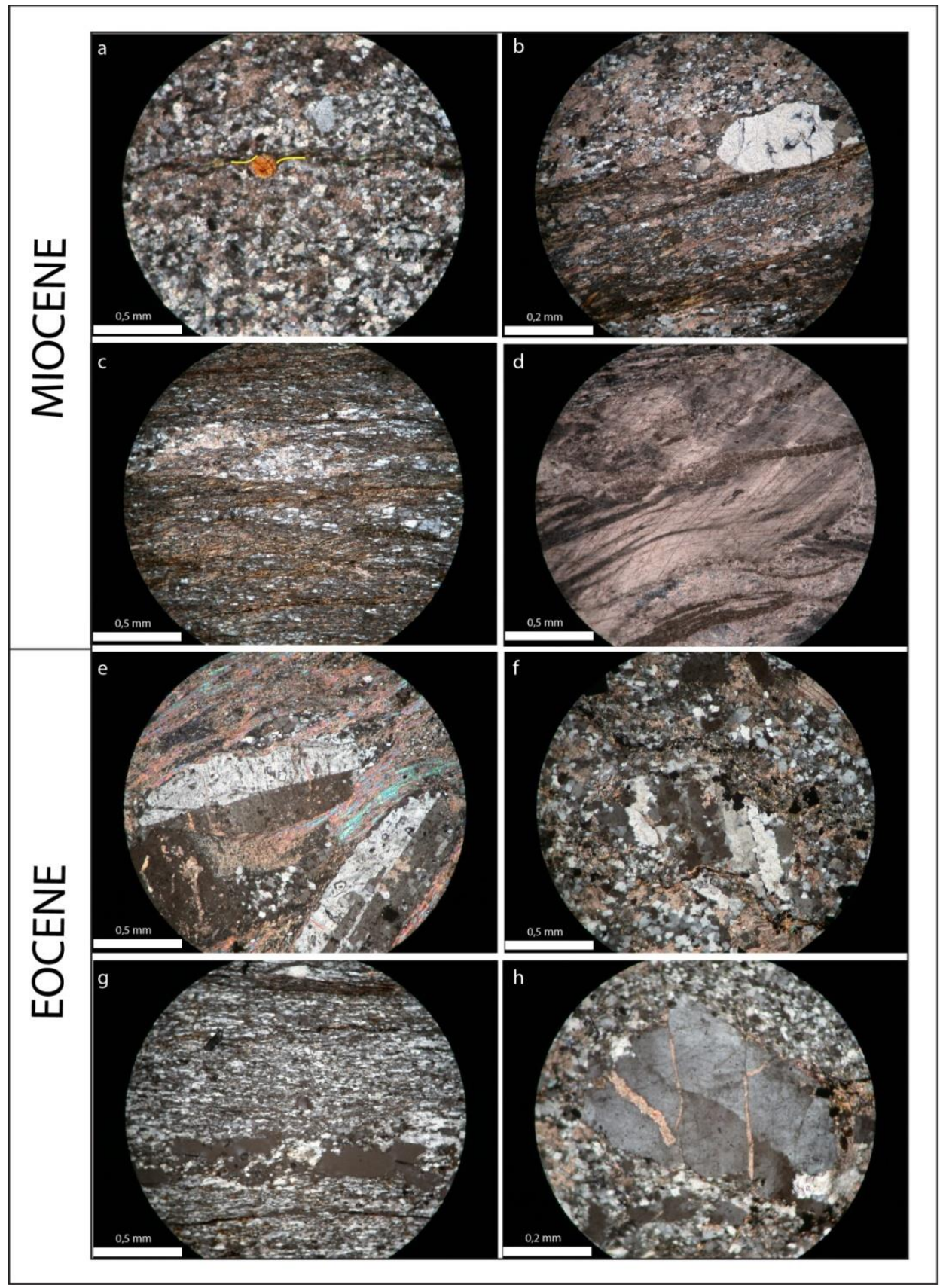

Figure 4 - Representative thin sections under cross polarized light (XPL) from Miocene and Eocene units. Miocene: a) Mica-calcite-quartz schist to quartzite (site 2A); b) and c) Calcphyllites (site 12D); d) Calcite marble lense within phyllites in plane polarized light (site 15E). Eocene: e) Chlorite-mica shicst (site 9C); f) and h) Mica-calcite-quartz schists to quartzites (site 18E); g) Phyllite (site 19F). 


\subsection{Geochemistry, structural data and GIS analysis}

PXRF measurements with sample coordinates, altitude, lineations and element analysis was imported in a GIS software (ESRI) to study the spatial distribution of major and minor elements in the area. Using a previous methodology (Marsellos et al., 2013) of separating the two metamorphic units through their stretching lineation (NNW-Miocene and NNE-Eocene) values, we calculated a representative average of the major elements geochemistry of each unit, which is summarized in Table 1. In the GIS software using the kriging function, a series of major and minor elements contour maps were created. $\mathrm{TiO}_{2}$ showed quantile QQ-plots with values closer to a normal distribution of the data, and resulted in the most significant contour map. In $\mathrm{TiO}_{2}$ contour map it is possible to distinguish two zones of titanium concentrations, regions in green that show concentrations from 0 $1,51 \%$ of $\mathrm{TiO}_{2}$ while regions in yellow show values higher than $1,51 \%$ (Fig.5).

Table 1 - Average concentrations (\% percentages) of major elements for Eocene and Miocene samples. *FeO is the total iron content.

\begin{tabular}{|l|l|l|l|l|l|l|l|l|l|}
\hline $\begin{array}{l}\text { Metamorphic } \\
\text { unit }\end{array}$ & $\mathrm{SiO}_{2}$ & $\mathrm{Al}_{2} \mathrm{O}_{3}$ & $\mathrm{FeO}^{*}$ & $\mathbf{M n O}$ & $\mathbf{M g O}$ & $\begin{array}{c}\mathbf{C a O} \\
+ \\
\mathbf{N a}_{2} \mathbf{O}\end{array}$ & $\mathbf{K}_{2} \mathbf{0}$ & $\mathbf{T i O}_{2}$ & Total \\
\hline $\begin{array}{l}\text { Miocene } \\
\mathbf{N = 8 3}\end{array}$ & 49.16 & 21.26 & 12.09 & 0.41 & 2.27 & 5.17 & 7.01 & 1.97 & 99.34 \\
\hline $\begin{array}{l}\text { Eocene } \\
\mathbf{N = 4 9}\end{array}$ & 50.14 & 20.82 & 10.6 & 0.48 & 2.09 & 7.36 & 6.59 & 1.68 & 99.76 \\
\hline
\end{tabular}

\section{Discussion and conclusions}

Miocene and Eocene units at Athinios harbour show similar petrographic and geochemical features, being distinguished only by their different stretching lineations and thermochronological ages, which suggest that both units have undergone the same stages of metamorphism, but were exhumed at different times. We confirm that Miocene unit was affected by arc-parallel extension while Eocene unit by arc-normal extension during its exhumation.

Analysing the petrography of the schists and phyllites, it is possible to note evidences of dynamic metamorphism. Microstructures and features such as quartz porphyroclasts showing undulose extinction, sub-grains formation and deformation bands, C-S structures marked by micas, rotated albite porphyroclasts and calcite deformed crystals showing twinning are indicators of plastic deformation mechanisms. The formation of some of these microstructures is due to the recovery process, in which, in order to decrease the strain/energy in crystal lattice, dislocations become rearranged and destroyed. During this process of recovery, dislocations align and create dislocation walls, which form sub-grains and undulose extinction. Recrystallized quartz grains express the process in which deformed grains with many dislocations are substituted by grains with few dislocations. In some of the samples analysed, recrystallized quartz presents an equigranular aspect, with no preferred orientation which indicates static recrystallization or annealing process, while in other samples quartz grains show alignment, evidence of recrystallization under differential stress. The deformation of phyllosilicates in framework phyllosilicate bands are also indicators of ductile deformation because under high temperatures/pressures these minerals rotate to align with the band and generate barriers to the fluid flow. 


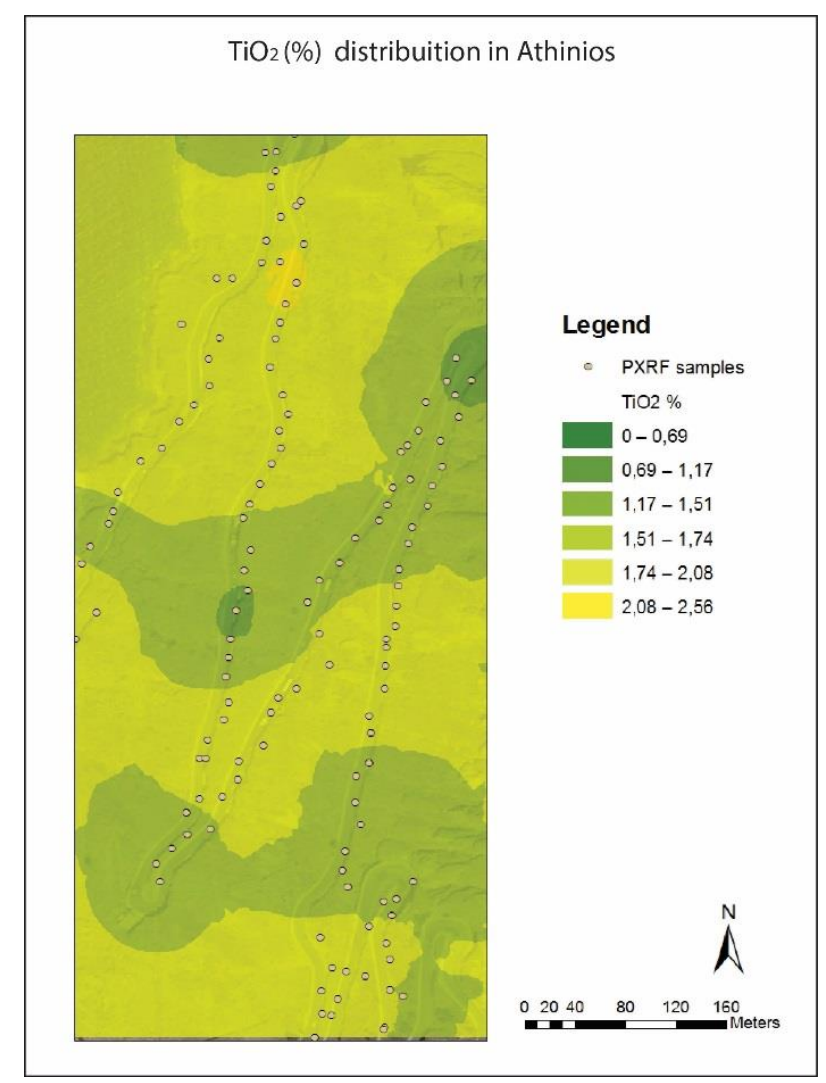

Figure 5 - $\mathrm{TiO}_{2}$ contour map. Dark green represents lower percentages of $\mathrm{TiO}_{2}$ and light green and yellow represent higher percentages.

Geochemistry values, together with petrography, suggest pelitic, calc-silicate and silisiclastic sedimentary rocks as protholiths for both units. $\mathrm{TiO}_{2}$ contour map shows a surprising pattern in which well delimited zones with high and low values of $\mathrm{TiO}_{2}$ concentration can be explained due to the geochemical behaviour of this element. Ti behaves as a high field strength element (HFSE) (Salters, 1998), hence it would not be easily remobilized even under hydrothermal alteration. Zones with a $\mathrm{TiO}_{2}$ enrichment would represent areas in which other elements were remobilized by hydrothermal fluids. Therefore, through $\mathrm{TiO}_{2}$ contour map and evidences of dynamic metamorphism found in petrography, it is possible to infer the presence of a ductile-brittle shear zone that, when active in Miocene, allowed fluids to go through its brittle portions and remobilize light elements provoking Ti enrichment and lead plastic deformation to occur in greater depth.

\section{Acknowledgments}

This work is a result of the Brazilian exchange program Science without Borders, sponsored by CNPq. Funding for sample analysis with PXRF and thin sections was provided by University of Brighton in United Kingdom. We thank Peter Lyons, Norman Moles, Martin Smith and Stewart Ullyott from University of Brighton for the support with sample analysis and advices. Part of the conference expenses are covered by ELKE of EKPA of University of Athens and by the Hofstra University. 


\section{References}

Altherr, R., Kreuzer, H.A.N.S., Wendt, I., Lenz, H., Wagner, G.A., Keller, J., Harre, W. and Hohndorf, A., 1982. A late Oligocene/early Miocene high temperature belt in the Attic-Cycladic crystalline complex (SE Pelagonian, Greece), Geologisches Jahrbuch E., 23, 97-164.

Andriessen, P.A.M., Boelrijk, N.A.I.M., Hebeda, E.H., Priem, H.N.A., Verdurnen, E.T. and Verschure, R.H., 1979. Dating the events of metamorphism and granitic magmatism in the Alpine Orogen of Naxos (Cyclades, Greece), Contributions to Mineralogy and Petrology, 69(3), 215-225.

Davis, E.N. and Bastas, C., 1978. Petrology and geochemistry of the metamorphic system of Santorini. In Thera and the Aegean World. 1, $61 \mathrm{pp.}$

Fassoulas, C., Kilias, A. and Mountrakis, D., 1994. Post-nappe stacking extension and exhumation of the HP/LT rocks in the island of Crete, Greece, Tectonics, 13, 127-138.

Fytikas, M. and Vougioukalakis, G., eds., 2005. The South Aegean Active Volcanic Arc: Present Knowledge and Future Perspectives, 7, Elsevier.

Jolivet, L., Faccenna, C., Goffé, B., Burov, E. and Agard, P., 2003. Subduction tectonics and exhumation of high-pressure metamorphic rocks in the Mediterranean orogens, American Journal of Science, 303(5), 353-409.

Keay, S., Lister, G. and Buick, I., 2001. The timing of partial melting, Barrovian metamorphism and granite intrusion in the Naxos metamorphic core complex, Cyclades, Aegean Sea, Greece, Tectonophysics, 342, 275-312.

Lister, G.S. and Snoke, A.W., 1984. SC mylonites. Journal of Structural Geology, 6(6), 617-638.

Marsellos, A.E. and Kidd, W.S.F., 2008. Extension and exhumation of the Hellenic forearc ridge in Kythera, The Journal of Geology, 116(6), 640-651.

Marsellos, A.E., Kidd, W.S.F. and Garver, J.I., 2010. Extension and exhumation of the HP/LT rocks in the Hellenic forearc ridge, American Journal of Science, 310(1), 1-36.

Marsellos, A., Foster, D.A., Kamenov, G.D. and Kyriakopoulos, K., 2012. Detrital zircon U-Pb data from the Hellenic south Aegean belts: constraints on the age and source of the South Aegean basement, Journal of the Virtual Explorer, 42, 1-12.

Marsellos, A., Foster, D.A., Min, K., Kidd, W.S.F., Garver, J.I. and Kyriakopoulos, K., 2013. An application of GIS analysis on structural data from metamorphic rocks in Santorini Island, Bulletin of the Geological Society of Greece, 47.

McClusky, S., Balassanian, S., Barka, A., Demir, C., Ergintav, S., Georgiev, I. and Kastens, K., 2000. Global Positioning System constraints on plate kinematics and dynamics in the eastern Mediterranean and Caucasus. Journal of Geophysical Research: Solid Earth, 1978-2012, 105(B3), 5695-5719.

Papazachos, B.C., Dimitriadis, S.T., Panagiotopoulos, D.G., Papazachos, C.B. and Papadimitriou, E.E., 2005. Deep structure and active tectonics of the southern Aegean volcanic arc, Developments in Volcanology, 7, 47-64.

Ring, U., Glodny, J., Will, T. and Thomson, S., 2010. The Hellenic subduction system: high-pressure metamorphism, exhumation, normal faulting, and large-scale extension, Annual Review of Earth and Planetary Sciences, 38, 45-76.

Salters, V.J.M., 1998. Elements: High Field strength. In: Marshall, C.P. and Fairbridge, R.W., eds., 1999, Encyclopedia of Geochemistry, Springer Science and Business Media, 21, 209-210.

Skarpelis, N. and Liati, A., 1990. The prevolcanic basement of Thera at Athinios: metamorphism, plutonism and mineralization, Thera and the Aegean World III, 2, 172-82.

Skarpelis, N., Kyriakopoulos, K. and Villa, I., 1992. Occurrence and ${ }^{40} \mathrm{Ar} /{ }^{39} \mathrm{Ar}$ dating of a granite in Thera (Santorini, Greece), Geologische Rundschau, 81/3, 729-735, Stuttgart 1992.

Skourtsos, E., and Lekkas, S. (2011). Extensional tectonics in Mt Parnon (Peloponnesus, Greece). International Journal of Earth Sciences, 100(7), 1551-1567.

Thomson, S.N., Stockhert, B. and Brix, M.R., 1999. Miocene high-pressure metamorphic rocks of Crete, Greece: rapid exhumation by buoyant escape, In: Ring, U., Brandon, M., Lister, G.S., and Willet, S.D., eds., Exhumation Processes: Normal Faulting, Ductile Flow and Erosion, Geological Society, London, Special Publication, 154, 87. 